\title{
The Effect of Guided Imagery to The Level of Anxiety of Trimester III Pregnant Woman in The Working Area of Mijen Health Center in Semarang City
}

\author{
${\text { Priharyanti Wulandari }{ }^{1} \text {, Alifia Sofitamia }}^{2}$, Menik Kustriyani ${ }^{3}$ \\ 1,2,3 Health Science Institute of Widya Husada Semarang
}

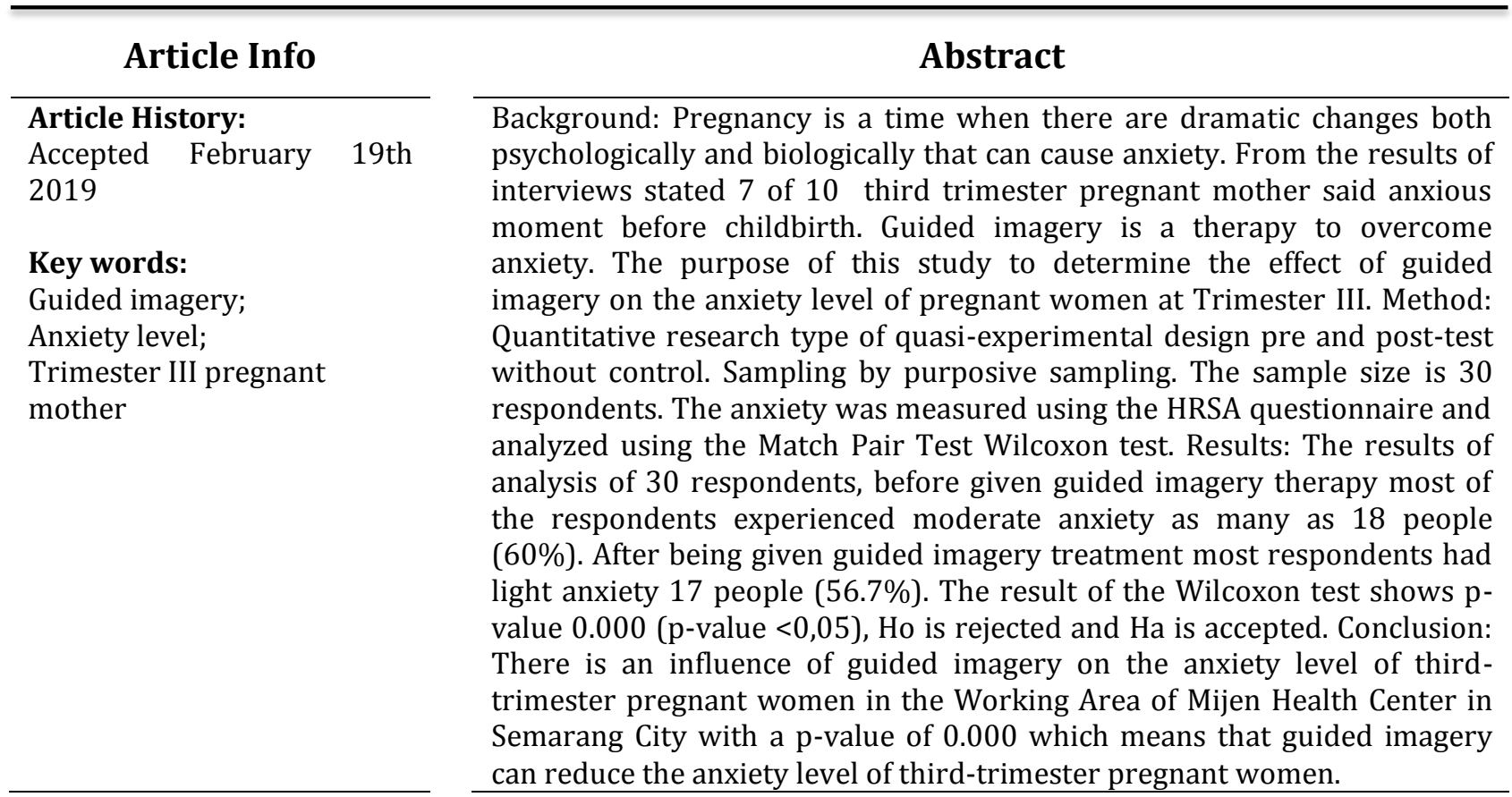

\section{PENDAHULUAN}

Menurut WHO ( Word Health Organization) tahun 2014 angka kematian ibu (AKI) di dunia yaitu 289.000 jiwa. Amerika serikat yaitu 9.300 jiwa, Afrika utara 179.000 jiwa, dan Asia Tenggara 16.000 jiwa. Angka kematian ibu di negara-negara di Asia Tenggara yaitu Indonesia menempati urutan pertama dengan 214 per 100.000 kelahiran hidup, Philipina 170 per 100.000 kelahiran hidup, Vietnam 160 per 100.000 kelahiran hidup, dan Malaysia 39 per 100.000 kelahiran hidup (WHO, 2014).
Angka kematian ibu di Indonesia tahun 2016 sebanyak 4.912 kasus, dan di tahun 2017 (semester I ) sebanyak 1.712, kasus kematian bayi di Indonesia tahun 2016 sebesar 32.007, dan ditahun 2017 di semester I sebanyak 10.294 kasus (Depkes RI, 2017). Angka kematian ibu (AKI) di Jawa Tengah pada tahun 2016 mencapai 602 kasus, sedangkan hingga semester I tahun 2017 AKI di Jawa Tengah tercatat sebanyak 215 kasus. Untuk kasus kematian bayi di Jawa Tengah pada tahun 2016 tercatat 5.485 kasus. Angka kematian ibu (AKI) di Kota Semarang bulan januari-juni 2017

Corresponding author:

Priharyanti Wulandari

wulancerank@yahoo.co.id

Media Keperawatan Indonesia, Vol 2 No 1, February 2019

e-ISSN: 2615-1669

DOI:10.26714/mki.2.1.2019.29-37 
tercatat 17 kasus (Dinkes Jateng, 2017). Banyak faktor penyebab angka kematian ibu (AKI) dan angka kematian bayi (AKB) salah satunya adalah kondisi emosional ibu selama kehamilan hingga kelahiran (Arini, 2013). Kecemasan (ansietas/ anxiety) adalah gangguan alam perasaan (affective) yang ditandai dengan perasaan ketakutan atau kekhawatiran yang mendalam dan berkelanjutan (Hawari, 2013). Periode kehamilan, persalinan, dan postnatal merupakan masa terjadinya stress yang hebat, kecemasan, gangguan emosi dan penyesuaian diri (Fraser dan Cooper, 2009).

Hasil penelitian yang dilakukan oleh Heriani (2016) menunjukkan bahwa 53,3\% (dari 45 responden wanita hamil) mengalami kecemasan dalam menghadapi persalinan. hasil penelitian yang dilakukan oleh Fazdria dan Meilani (2014) di dapatkan hasil bahwa dari 25 responden 12 (48\%) ibu hamil mengalami kecemasan berat dalam menghadapi persalinan, 12 (48\%) ibu hamil mengalami kecemasan sedang dan 1 (4\%) ibu hamil mengalami kecemasan ringan.

Kecemasan yang terjadi pada ibu hamil dapat mempengaruhi kesehatan ibu dan janin, perkembangan janin dapat terhambat atau dapat menggalami gangguan emosi saat lahir jika kecemasan selama kehamilan tidak ditanggani dengan baik (Dahro, 2012). Kecemasan dan stress yang terus menerus (berulang-ulang) selama masa kehamilan akan mempengaruhi perkembangan fisiologis dan psikologis janin. (Pieter dan Lumongga, 2013).

Masalah kecemasan pada ibu hamil tentang persalinan dapat diatasi dengan menggunakan tehnik farmakologis dan terapi non farmakologis. Salah satu tehnik non farmakologis yaitu Guided Imagery. Guided Imagery atau tehnik imajinasi terbimbing adalah pengembangan fungsi mental yang mengekspresikan diri secara dinamik melalui proses psikofisiologikal melibatkan seluruh indra dan membawa perubahan terhadap perilaku, persepsi, atau respon fisiologik dengan bimbingan seseorang atau melalui media (Nurgiwati, 2015). Guided imagery di lakukan dengan cara membayangkan waktu, kejadian yang menyenangkan atau tempat favorit menggunakan semua indranya, pemandangan, suara, bau, perasaan, menghasilkan respon emosional yang positif sebagai distraksi yang menyenangkan untuk mengalihkan perhatian dari suatu ketidaknyamanan ataupun rasa sakit (Rossman, 2017).

Hasil penelitian yang dilakukan oleh Apriyanto (2013) menunjukkan hasil penelitian bahwa tehnik imaginasi terbimbing lebih efektif menurunkan tingkat kecemasan dibandingkan dengan tehnik nafas dalam. Hasil penelitian Purnama, (2015) menunjukkan bahwa guided imagery dapat menurunkan tingkat kecemasan menjelang persalinan pada ibu hamil pada ketiga partisipan. Hal ini dapat terjadi dikarenakan guided imagery mengajarkan untuk fokus pada imajinasi positif yang dapat menimbulkan keadaan yang rileks.

Dari identifikasi masalah tersebut maka peneliti merumuskan masalah dalam penelitian ini adalah Apakah ada pengaruh guided imagery terhadap tingkat kecemasan pada ibu hamil trimester ke III di wilayah kerja Puskesmas Mijen Kota Semarang?

\section{METODE}

Jenis penelitian yang digunakan dalam penelitian ini adalah penelitian kuantitatif dangan menggunakan design Quasi Eksperimen Pretest-post test With Out Control Group. Sampel dalam penelitian ini sebanyak 30 responden. Pengambilan sampel menggunakan 2 tehnik, tehnik pengambilan sampel wilayah kerja menggunakan cluster random sampling dan tehnik pengambilan sampel individu menggunakan purposive sampling. Penelitian ini dilakukan di Wilayah Kerja Puskesmas Mijen Kota Semarang, 
engambilan data dilakukan pada tanggal 20 mei - 10 juni 2018.

Alat pengumpulan data yang digunakan dalam penelitian ini adalah kuesioner kecemasan dari Hamilton Rating Scale for Anxiety (HRSA). Pengukuran variabel kecemasan dilakukan sebelum dan sesudah perlakuan, analisis meliputi analisa univariat dan bivariat. Analisa univariat menggambarkan distribusi frekuensi berdasarkan umur, paritas dan tingkat pendidikan. Analisa bivariat dilakukan dengan uji wilcoxon, dan dianalisis perbedaan tingkat kecemasan sebelum dan tingkat kecemasan setelah intervensi.

\section{HASIL PENELITIAN}

Responden dalam penelitian ini berjumlah $30 \mathrm{ibu}$ hamil trimester III. Responden berdasarkan usia, diperoleh hasil bahwa usia ibu hamil trimester III di dominasi usia 20-35 tahun yaitu sebanyak 27 responden (90\%), diikuti dengan ibu hamil trimester III yang berusia $>35$ tahun yaitu sebanyak 2 responden $(6,7 \%)$ dan yang terendah adalah ibu hamil trimester III yang berusia kurang dari 20 tahun sebanyak 1 responden $(3,3 \%)$.

Distribusi frekuensi ibu hamil trimester III berdasarkan gravida, diperoleh hasil ibu hamil trimester III didominasi oleh multi gravida yaitu sebanyak 24 responden (80\%) dan diikuti oleh primi gravida yaitu sebanyak 6 responden (20\%).

Distribusi frekuensi ibu hamil trimester III berdasarkan Pendidikan, dapat diketahui bahwa sebagian besar ibu hamil trimester III berpendidikan SMP yaitu sebanyak 14 responden $(46,7 \%)$, dikuti oleh ibu hamil trimester III dengan pendidikan SMA sebanyak 13 orang $(43,3 \%)$, dan ibu hamil dengan pendidikan Perguruan Tinggi sebanyak 3 orang $(10,0 \%)$.
Responden berdasarkan tingkat kecemasan ibu hamil trimester III diperoleh hasil bahwa dari 30 responden distribusi frekuensi tertinggi yaitu responden dengan tingkat kecemasan sedang sebanyak 18 responden $(60,0 \%)$, selanjutnya tingkat kecemasan ringan yaitu sebanyak 6 orang $(20,0 \%)$, dan responden dengan tingkat kecemasan berat sebanyak 6 orang $(20,0 \%)$.

Tingkat kecemasan ibu hamil sesudah pemberian guided imagery therapy diperoleh hasil bahwa dari 30 responden distribusi frekuensi tingkat kecemasan tertinggi adalah tingkat kecemasan ringan dengan 17 responden (56,7\%), diikuti dengan tingkat kecemasan tidak ada kecemasan yaitu sebanyak 9 orang $(30,0 \%)$, dan distribusi frekuensi tingkat kecemasan terendah yaitu tingkat kecemasan sedang sesudah pemberian guided imagery therapy sebanyak 4 orang $(13,3 \%)$.

\section{Tabel 1}

Pengaruh Guided Imagery Terhadap

Tingkat Kecemasan Ibu Hamil Trimester III di Wilayah Kerja Puskesmas Mijen Kota Semarang

\begin{tabular}{lcrc}
\multicolumn{4}{c}{$\mathbf{n = 3 0}$} \\
$\begin{array}{l}\text { Tingkat } \\
\text { kecemasan }\end{array}$ & Frekuensi & $\begin{array}{c}\mathbf{Z} \\
\text { hitung }\end{array}$ & $\boldsymbol{p}$ \\
\hline Negative Rank & 30 & -5.203 & 0,000 \\
Positive Rank & 0 & & \\
Ties & 0 & & \\
\hline Jumlah & $\mathbf{3 0}$ & & \\
\hline
\end{tabular}

Hasil uji statistik dengan uji Wilcoxon Match Pair Test menunjukan hasil nilai Z Hitung 5.203 dan nilai $p$-value $=0,000<\alpha 0,05$. Dengan demikian jika $p=0.000<\alpha 0,05$ maka Ha diterima dan Ho ditolak yang artinya bahwa ada Pengaruh Guided Imagery Terhadap Tingkat Kecemasan Ibu Hamil Di Wilayah Kerja Puskesmas Mijen Kota Semarang. 


\section{PEMBAHASAN}

\section{Usia}

Usia ibu hamil dalam penelitian ini berada pada usia yang aman untuk hamil dan melakukan persalinan yaitu 20-35 tahun, hal ini sesuai dengan teori yang dikemukakan Janiwarti dan Pieter (2013) bahwa batasan yang relatif paling aman dari segi reproduksi sehat dimana seseorang ibu bisa mengandung dengan aman apabila mendapat pemeliharaan yang baik selama masa mengandung adalah rentan usia dari 20-35 tahun.

Hal ini sejalan dengan penelitian Fazria \& Meilani (2014) yang menyatakan bahwa untuk umur yang paling aman menjalani kehamilan dan persalinan adalah usia 20-35 tahun, dalam rentang usia ini kondisi fisik wanita dalam keadaan prima, sedangkan usia $<20$ tahun dan $>35$ tahun sebagian wanita digolongkan pada kehamilan beresiko tinggi terhadap kelainan bawaan dan adanya penyulit pada waktu persalinan.

Hasil penelitian ini sejalan dengan penelitian Astria (2014) yang menyatakan dari 158 responden pada kategori umur sebagian besar responden memiliki umur tidak beresiko tinggi (20-35 tahun) pada umur tersebut ibu hamil cenderung dapat menggalami kecemasan pada saat proses persalinan.

\section{Paritas}

Berdasarkan hasil penelitian dengan jumlah sampel 30 responden diketahui bahwa mayoritas adalah multigravida sebanyak 24 responden (80\%). Hasil penelitian ini menunjukan bahwa paritas merupakan faktor yang berpengaruh tingkat terhadap kecemasan ibu hamil trimester III dalam menghadapi persalinan karena masingmasing ibu mempunyai pandangan yang berbeda-beda tergantung dari pengalaman tentang proses persalinan.
Paritas dapat mempengaruhi tingkat kecemasan dimana paritas merupakan faktor yang bisa dikaitkan dengan faktor psikologis, pada ibu primigravida, belum ada bayangan mengenai apa yang akan terjadi saat bersalin hal ini akan mempengaruhi proses berfikir ibu tentang proses persalinan yang dapat menimbulkan rasa cemas, sedangkan pada multigravida perasaan cemas dapat terjadi karena rasa sakit dari pengalaman saat melahirkan sebelumnya (Amalia, 2009).

Menurut hasil penelitian dari Asfiati (2014) bahwa paritas dapat mempengaruhi tingkat kecemasan ibu hamil dalam menghadapi proses persalinan, semakin sering seseorang menjalani persalinan, maka akan semakin tinggi pula rasa percaya diri dalam menjalani kehamilan, sehingga kecemasan yang dialami dapat teratasi.

Hal ini sejalan dengan hasil penelitian Astria (2014) bagi primigravida kehamilan yang dialami nya merupakan pengalaman pertama kali, sehingga trimester III dirasakan semakin mencemaskan karena semakin dekat dengan proses persalinan. Ibu akan cenderung merasa dengan kehamilannya, merasa gelisah, dan takut menghadapi persalinan, mengingat ketidaktahuan menjadi faktor penunjang terjadinya kecemasan. Sedangkan ibu yang pernah hamil sebelumnya (multigravida), dapat pula mengalami kecemasan berhubungan dengan pengalaman masa lalu yang pernah dialami.

\section{Tingkat Pendidikan}

sebagian besar ibu hamil trimester III dengan pendidikan SMP yakni sebanyak 14 responden (46,7\%). Tingkat pendidikan secara tidak langsung mempengaruhi tingkat kecemasan seseorang, menurut Struat \& Sundeen, (1998 dalam Aulia 2015) bahwa semakin rendah tingkat pendidikan akan berpengaruh terhadap kemampuan berpikir, ini dikarenakan akan berpengaruh terhadap kemampuan berpikir, semakin tinggi tingkat pendidikan seseorang akan 
semakin mudah berpikir rasional dan menangkap informasi baru termasuk dalam memecahkan masalah baru.

Hal ini sejalan dengan hasil penelitian Asfiati (2014) yang menyatakan pendidikan merupakan faktor yang mempengaruhi kecemasan pada ibu hamil karena pendidikan merupakan peran penting dalam proses tumbuh kembang seluruh kemampuan dan perilaku manusia. Dengan pendidikan manusia dianggap akan memperoleh pengetahuan. Seorang ibu hamil dengan pendidikan tinggi akan dapat mengendalikan emosi dan menekan perasaan cemas saat menghadapi perubahan-perubahan yang terjadi pada kehamilan dan menghadapi persalinan.

Penelitian ini sejalan dengan penelitian Heriani (2016) bahwa ibu hamil dengan pendidikan rendah akan semakin mudah seseorang mengalami tress dan kecemasan dibandingkan dengan ibu hamil dengan pendidikan tinggi, dimana stress dan kecemasan yang terjadi karena kurangnya informasi yang didapatkan orang tersebut. Hal ini juga sejalan dengan penelitian Astria (2014) yang menyatakan bahwa ibu hamil yang berpendidikan bawah dan menengah cenderung lebih banyak menggalami kecemasan dari pada ibu hamil berpendidikan tinggi.

\section{Tingkat Kecemasan Sebelum Diberikan}

\section{Guided Imagery}

Berdasarkan hasil penelitian ini menunjukan bahwa sebagian besar ibu hamil trimester III di wilayah kerja puskesamas mijen kota semarang sebelum diberikan guided imagery therapy menggalami kecemasan sedang. Pada kecemasan sedang memungkinkan seseorang untuk memusatkan pada hal yang penting dan mengesampingkan yang tidak penting. kecemasan dapat mempersempit lapang persepsi individu. Respon fisiologis yang dialami pada tingkat kecemasan sedang antara lain sering nafas pendek, nadi ekstra systole dan tekanan darah naik, mulut kering, anorexia, diare/konstipasi, gelisah (Manurung, 2016).

Penyebab kecemasan yang dialami oleh ibu hamil trimester III diantaranya adalah kecemasan yang disebabkan karena rasa takut jika persalinannya bermasalah, khawatir bayi yang dilahirkan nya akan lahir cacat, dan kecemasan karena membayangkan rasa sakit saat bersalin. Selain itu menurut Nurdiana (2012) rasa cemas yang dialami oleh ibu hamil itu disebabkan karena meningkatnya kadar hormon progesteron. Hornom ini dapat membuat ibu hamil merasa cemas, peningkatan hormon ini juga menyebabkan gangguan perasaan dan membuat ibu cepat lelah. Hormon lain yang meningkat selama kehamilan adalah hormon adrenalin. Hormon adrenalin dapat menimbulkan disregulasi biokimia tubuh sehingga muncul ketegangan fisik pada ibu hamil seperti mudah marah, gelisah, tidak mampu memusatkan pikiran, dan cemas.

Dalam penelitian ini faktor-faktor yang mempengaruhi kecemasan ibu hamil trimester III adalah usia ibu hamil, gravida dan pendidikan ibu hamil. Pada penelitian ini usia ibu rata-rata adalah 20-35 tahun yaitu sebanyak 27 responden atau dalam presentase 90\%, hal ini berpengaruh terhadap kecemasan ibu hamil trimester III yang rata-rata adalah cemas sedang yaitu sebanyak 18 responden (60\%). Hal ini sejalan dengan penelitian Fazria \& Meilani yang menyatakan bahwa dari 25 responden, 3 responden yang berusia $<20$ tahun seluruhnya mengalami kecemasan berat, dan 18 responden yang berusia 20-35 tahun mayoritas memiliki gejala cemas sedang dan dari 4 responden yang berusia >35 tahun 2 responden memiliki gejala cemas sedang dan 2 responden mengalami cemas berat. Hal ini dikarenakan ibu hamil usia $<20$ tahun mengalami kecemasan berat akibat kondisi fisik belum $100 \%$ siap untuk hamil dan melahirkan. Untuk umur paling aman menjalani kehamilan dan persalinan adalah usia 20-35 tahun, di rentang usia ini 
kondisi fisik dan psikologis dalam kondisi matang. Sedangkan setelah usia 35 tahun sebagian wanita digolongkan dalam kehamilan beresiko tinggi terhadap kelainan kehamilan dan adanya penyulit pada waktu persalinan, sehingga akan meningkatkan kecemasan.

Faktor yang berpengaruh terhadap kecemasan ibu hamil trimester III dalam penelitian ini selain usia adalah gravida dan tingkat pendidikan ibu hamil trimester III. Dalam penelitian ini rata-rata ibu hamil trimester III berpendidikan SMP yaitu sebanyak 14 responden $(46,7 \%)$ dan sisanya pendidikan SMA sebanyak 13 orang (43,3\%), dan ibu hamil dengan pendidikan Perguruan Tinggi sebanyak 3 orang $(10,0$ $\%)$.

Menurut manuaba dalam Pasaribu (2014) yang menyatakan semakin tinggi pendidikan seseorang maka semakin besar peluang untuk mencari pengobatan ke pelayanan kesehatan. Sebaliknya rendahnya pendidikan seseorang akan menyebabkan seseoran mengalami stress, dimana tress dan kecemasan yang terjadi disebabkan kurangnya informasi yang didapatkan orang tersebut. Hasil penelitian ini sejalan dengan penelitian Heriani 2016 yang menyatakan ibu hamil yang berpendidikan rendah dari 23 responden 17 (74\%) diantaranya mengalami kecemasan dan 6 responden $(31,8 \%)$ tidak mengalami kecemasan. Penelitian ini juga sejalan dengan Kanianingsih (2015) yang menyatakan ada hubungan yang signifikan antara umur, gravida dan tingkat pendidikan dengan kecemasan dalam menghadapi proses persalinan.

\section{Tingkat Kecemasan Setelah Diberikan}

\section{Guided Imagery.}

Berdasarkan data tersebut diperoleh hasil bahwa terdapat penurunan tingkat kecemasan ibu hamil trimester III sesudah pemberian guided imagery therapy. Hal ini dapat terjadi dikarenakan guided imagery mengajarkan untuk berfokus pada imajinasi positif yang dapat menimbulkan keadaan yang rileks. Saat tubuh dalam keadaan rileks, saraf parasimpatis akan bekerja menekan saraf simpatis (Nguyen, 2012).

Guided imagery pada dasarnya mengarahkan diri sendiri untuk berfikir dan berimajinasi secara positif sehingga merangsang serotonin untuk mengeluarkan zat kimiawi yang bersifat menyenangkan sehingga menurunkan kecemasan dan dapat menurunkan respon simpatik terhadap stress dan membantu proses penyembuhan diri sendiri (self healing). Guided imagery juga merangsang kelenjar pituitary untuk menghasilkan hormon endorphin yang meimbulkan efek bahagia, senang bagi pasien (Nurgiwati, 2015).

Seseorang yang mengalami kecemasan seringkali terfokus pada pemikiran negatif, perasaan takut dan khawatir terhadap hal yang terjadi dimasa yang akan datang tanpa alasan yang jelas (Purnama, 2015). Pada guided imagery, partisipan diminta untuk berfokus pada pengalaman yang menyenangkan serta melibatkan indera untuk ikut merasakan keindahan tersebut. Dengan membayangkan waktu dan tempat favorit dalam semua semua keindahanya dengan menggunakan seluruh indra, hal itu dapat menghasilkan respon emosional yang positif sebagai distraksi yang menyenangkan untuk mengalihkan perhatian dari suatu ketidaknyamanan (Naparstek 2007 dalam Purnama 2015).

Dari hasil penelitian ini diketahui bahwa seluruh responden mengalami penurunan tingkat kecemasan.

Berdasarkan hasil penelitian yang dilakukan terhadap 30 responden ibu hamil trimester III diwilayah kerja puskesmas mijen kota semarang didapatkan hasil bahwa dari 30 responden seluruhnya mengalami penurunan tingkat kecemasan dengan nilai $\mathrm{Z}$ hitung - 5.203 dan nilai pvalue $=0,000<0,05$ dengan demikian maka Ha diterima dan Ho ditolak yang artinya 
bahwa ada pengaruh guided imagery terhadap tingkat kecemasan ibu hamil trimester III di Wilayah Kerja Puskesmas Mijen Kota Semarang. Hal ini dapat dijelaskan bahwa nilai Z hitung $-5.203<\mathrm{Z}$ tabel 1,96 dan nilai $p$-value $=0,000<0,05$ menunjukkan bahwa guided imagery berpengaruh positif terhadap penurunan tingkat kecemasan ibu hamil trimester III di Wilayah Kerja Puskesmas Mijen Kota Semarang.

Hasil penelitian ini sejalan dengan penelitian Purnama, (2015) yang menunjukkan bahwa guided imagery dapat menurunkan tingkat kecemasan menjelang persalinan pada ibu hamil pada ketiga partisipan. Hal ini dapat terjadi dikarenakan guided imagery mengajarkan untuk fokus pada imajinasi positif yang dapat menimbulkan keadaan yang rileks. Saat tubuh dalam keadaan rileks saraf parasimpatik bekerja menekan saraf simpatik saat cemas.

Hal ini sejalan dengan hasil penelitian Jallo et al, (2014) berdasarkan penelitian pada ibu hamil Afrika-Amerika dengan membandingkan kadar CRH (Corticotropin Relasing Hormon) antara yang di berikan intervensi guided imagery dengan usual care menunjukan bahwa intervensi guided imagery efektif dalam mengurangi kecemasan, tekanan, dan kelelahan yang dialami oleh wanita Afrika Amerika yang sedang hamil.

Hasil penelitian ini sejalan dengan penelitian yang dilakukan oleh Apriyanto (2013) menunjukkan hasil penelitian bahwa tehnik imaginasi terbimbing lebih efektif menurunkan tingkat kecemasan dibandingkan dengan tehnik nafas dalam. hal ini dikarenakan tehnik guided imagery akan membentuk suatu bayangan yang indah, hal tersebut akan memberikan perasaan tenang, ketegangan serta ketidaknyamanan dapat dikeluarkan dari dalam tubuh, maka menyebabkan tubuh menjadi rileks dan nyaman.
Hasil penelitian ini membuktikan bahwa guided imagery yang dilatih kepada setiap responden berperan penting dalam mengurangi kecemasan yang dialami ibu hamil saat hamil trimester III dan menjelang persalinan. Terbukti dengan terapi ini memberikan banyak manfaat positif kepada setiap masing-masing responden, yang didapat melalui hasil wawancara peneliti di akhir sesi pertemuan, responden dapat lebih rileks dan nyaman serta dapat meyakini dirinya sendiri bahwa persalinan nya akan berjalan dengan lancar.

Menurut peneliti guided imagery dapat dipertimbangkan sebagai terapi untuk mengatasi kecemasan yang dialami ibu hamil trimester III dalam enghadapi proses persalinan, dimana terapi ini sangat sederhana, mudah dilakukan, efektif dan tidak memiliki efek samping, sehingga dengan terapi ini nantinya dapat meningkatkan derajat kesehatan ibu hamil dan mengurangi efek buruk dari kecemasan yang dialami ibu hamil ataupun janin dan dapat mengurangi angka kematian ibu dan angka kematian bayi.

\section{SIMPULAN}

Tingkat kecemasan ibu hamil trimester III yang berada di Wilayah Kerja Puskesmas Mijen Kota Semarang sebelum diberikan guided imagery therapy menunjukkan bahwa sebagian besar responden mengalami tingkat kecemasan sedang yaitu sebanyak 18 responden $(60,0 \%)$, selanjutnya tingkat kecemasan ringan sebanyak 6 orang $(20,0 \%)$, tingkat kecemasan berat sebanyak 6 orang $(20,0 \%)$. Hal ini menunjukkan bahwa hampir keseluruhan ibu hamil trimester III mengalami kecemasan dalam menghadapi kehamilan trimester III dan kecemasan dalam proses persalinan.

Tingkat kecemasan ibu hamil trimester III di Wilayah Kerja Puskesmas Mijen Kota Semarang sesudah pemberian guided imagery therapy menunjukan data bahwa 
rata-rata ibu hamil mengalami tingkat kecemasan ringan dengan 17 responden (56,7\%), diikuti dengan tingkat kecemasan tidak ada kecemasan yaitu sebanyak 9 orang $(30,0 \%)$, dan tingkat kecemasan sedang 4 orang $(13,3 \%)$. Hal ini menunjukkan bahwa terdapat penurunan tingkat kecemasan pada ibu hamil trimester III yang berada di Wilayah Kerja Puskesmas Mijen Kota Semarang sesudah diberikan guided imagery therapy.

Berdasarkan hasil uji statistik Wilcoxon Match Pair Test dapat diketahui $\mathrm{p}$ value sebesar 0,000 < 0,05, maka Ho di tolak dan Ha diterima yang menunjukan ada penggaruh guided imagery terhadap tingkat kecemasan ibu hamil trimester III di Wilayah Kerja Puskesmas Mijen Kota Semarang. hasil penelitian ini menunjukan semua responden mengalami penurunan kecemasan.

\section{REFERENSI}

Amalia, Titian. 2009. Kecemasan Ibu Menanti Persalinan. Jakarta: Nuha Medika

Aprianto, Dino. 2013. Efektifitas Teknik Relaksasi Imajinasi Terbimbing Dan Nafas Dalam Terhadap Penurunan Kecemasan Pada Pasien Pre Operasi. Semarang : Poltekes Kemenkes Semarang, Volume 13, No 2, 2017. tersedia dalam http://ejurnal.poltekkestjk.ac.id/index.php/JKEP/article/view/938, Diakses tanggal 15 juni 2018.

Asfiati, Nur. 2014. Faktor-Faktor Yang Berhubungan Dengan Tingkat Kecemasan Ibu Hamil Dalam Menghadapi Proses Persalinan Di Wilayah Kerja Puskesmas Tomia Induk Kabupaten Wakatobi. Buton: STIKES IST, Volume. 1 Nomor. 11 Agustus 2013.https://media.neliti.com/media/publica tions/ 109817-ID-faktor-faktor-yangberhubungan-dengan-ke.pdf, Diakses tanggal 28 juni 2018

Astria, Y. 2014. Hubungan Karakteristik Ibu Hamil Trimester III Dengan Kecemasan Dalam Menghadapi Persalinan Di Poliklinik Kebidanan Dan Kandungan RSUP Fatmawati. Jakarta: Fakultas Kedokteran dan Ilmu Kesehatan, UIN Syarif Hidayatullah. Volume 12, No 2, tahun 2014. http://jurnal.unpad.ac.id/mku/article/view/ 95, Diakses tanggal 1 juli 2018.

Aulia. 2014. Hamil Sehat Dengan Beragam Olahraga Ibu Hamil. Jogjakarta: Buku Biru

Darho, Ahmad. 2012. Psikologi Kebidanan : Analisis Perilaku Wanita Untuk Kesehatan. Jakarta : Salemba Medika

Departemen Kesehatan RI. 2017. Profil Kesehatan Indonesia. Jakarta

Dinas Kesehatan Jawa Tengah. 2017. Profil Kesehatan Provinsi Jawa Tengah. Semarang

Fazdria \& meliani .S. H. 2014. Gambaran Tingkat Kecemasan Pada Ibu Hamil Dalam Menghadapi Persalinan Di Desa Tualang Teungoh Kecamatan Langsa Kota Kabupaten Kota Langsa Tahun 2014. Aceh : Poltekes Kemenkes Aceh. Volume 16, No 1, Tahun 2014.

http://www.jurnal.unsyiah.ac.id/JKS/article/ view/5003, Diakses pada 16 februari 2018

Fraser, D.M, \& Cooper M.A. 2009. Buku Ajar Bidan Myles (Myles Textbook For Midwives) Edisi 14. Jakarta : EGC

Hawari, Dadang. 2013. Manajemen Stress Cemas Dan Depresi. Jakarta :FKUI

Heriani. 2016. Kecemasan Dalam Menjelang Persalinan Ditinjau Dari Paritas, Usia dan Tingkat Pendidikan. Lampung: STIKES Aisyah Pringsewu, Volume 1, No 2, Tahun 2016, tersedia di https://ejournal.stikesaisyah.ac.id/index.php /jika/article/view/Heriani/0, Diakses pada 19 februari 2018

Jallo et al. 2014. Guided Imagery for Stress and Symptom Management in Pregnant African American Women. USA : Virginia Commonwealth University, Volume 2014, Article ID 84092, Tahun 2014. https://www.hindawi.com/journals/ecam/20 14/840923/. Diakses tanggal 20 januari 2018

Janiwarty dan pieter. 2013. Pendidikan Psikologi Untuk Kebidanan. Yogyakarta: Rapha Publishing

Kanianingsih, Nunung. 2015. Gambaran Tingkat Kecemasan Ibu Hamil Trimester III Dalam Menghadapi Proses Persalinan. Volume 12, No 3, Tahun $2015 \quad$ http://www.ejurnal.com/2015/05/gambaran-tingkat- 
kecemasan-ibu-hamil.html, Diakses Tanggal 12 Juli 2018

Manurung, Nixson. 2016. Terapi Reminiscence. Jakarta: Trans Info Media

Nguyen. Tong Thi-Ngoc. 2012. Utilization of guided imagery whitin the four phase of adlerian therapy. Researc Paper. The Faculty of The Adler Graduate School. http://alfredadler.edu/sites/default/files/Ng uyen_MP_2012.pdf Diakses tanggal 27 juli 2018

Nurgiwati, Endeh. 2015. Terapi Alternatif Dan Komplementer Dalam Bidang Keperawatan. Bogor : In Media

Pasaribu. 2014. Hubungan Paritas, Usia Dan Pendidikan Dengan Tingkat Kecemasan Ibu Hamil Trimester III Dalam Menghadapi Persalinan Di Puskesmas Sipea-Pea Kecamatan Sorkam Barat. Sibolga. STIKES Nauli Husada Sibolga, Volume 1, No 2, Tahun 2014. https://ejournal.stikesaisyah.ac.id/index.php /jika/article/view/Heriani, Diakses pada tanggal 1 juli 2018

Pieter Herry. Z \& Lumongga .L Namora. 2013. Pengantar Psikologi Untuk Kebidanan edisi revisi. Jakarta : Kencana Prenada Media Group

Purnama, Baik W. R. 2015. Guided Imagery Terhadap Tingkat Kecemasan Menjelang Perselinan Pada Ibu Hamil. Malang: Universitas Muhammadiyah Malang, Volume 3, No 2, Agustus 2015, http://ejournal.umm.ac.id/index.php/jipt/art icle/viewFile/3533/4066,Diakses pada 15 januari 2018

Rossman, Martin L. 2017. Guided Imagery And Interactive Guided Imagery. Callifornia: Academy for Guided Imagery

WHO. 2014. Angka Kematian Ibu. Diperoleh dari http://theprakasa.org. Diakses tanggal 14 januari 